\title{
Influence of the size and form of Artemia sp. nauplii on the growth and survival of Atlantic sturgeon (Acipenser oxyrinchus Mitchill) larvae
}

\author{
Iwona Piotrowska, Bożena Szczepkowska, Michał Kozłowski
}

Received - 20 January 2021/Accepted - 15 May 2021. Published online: 30 June 2021; @Inland Fisheries Institute in Olsztyn, Poland Citation: Piotrowska, I., Szczepkowska B., Kozłowski M. (2021). Influence of the size and form of Artemia sp. nauplii on the growth and survival of Atlantic sturgeon (Acipenser oxyrinchus Mitchill) larvae. Fisheries Aquatic \& Life 29, 69-79

\begin{abstract}
The aim of the study was to determine the influence of the size and form of Artemia sp. feed on the rearing indices of Atlantic sturgeon larvae. In the experiment, the nauplius sizes used were $480 \mu \mathrm{m}$ (group AD), $430 \mu \mathrm{m}$ (group AM), and $430 \mu \mathrm{m}$ frozen nauplii (group AI). After three weeks of rearing, the sturgeon from group $\mathrm{AD}$ had the highest mean body weight of $0.131 \mathrm{~g}$ that was statistically significantly different from groups AM (0.071 g) and AI (0.033 g). The longest total length was noted in group $\mathrm{AD}(2.8 \mathrm{~cm})$ and was statistically different from the others $(\mathrm{P} \leq 0.05)$. Specific growth rate in groups $\mathrm{AD}$ and $\mathrm{AM}$ was 14.7 and $11.8 \% \mathrm{~d}^{-1}$, respectively, and these values differed statistically from those in group AI at $7.8 \% \mathrm{~d}^{-1}$. The highest survival rate was recorded in group $\mathrm{AD}$ at $60.6 \%$, while the lowest was noted in group $\mathrm{AI}$ at $15.6 \%$, and the differences between these two groups were statistically significant. The results of the experiment indicated that a feed of live $480 \mu \mathrm{m}$ Artemia sp. nauplius significantly accelerated the growth rates and increased the survival rates of Atlantic sturgeon larvae.
\end{abstract}

Keywords: Acipenser oxyrinchus, aquaculture, Artemia sp., larvae, live and frozen feed

\footnotetext{
I. Piotrowska [ ఏ], B. Szczepkowska, M. Kozłowski

Department of Sturgeon Fish Breeding, S. Sakowicz Inland Fisheries Institute in Olsztyn

11-610 Pozezdrze, Pieczarki 50, Poland

E-mail: i.piotrowska@infish.com.pl
}

\section{Introduction}

The Atlantic sturgeon, Acipenser oxyrinchus (Mitchill), is one of the largest fishes currently occurring in the Baltic Sea catchment area. Thanks to restoration and strict conservation measures, this species once again inhabits European waters (Stakènas and Pilinkovskij 2019). Work to reconstruct the Baltic population of Atlantic sturgeon in Poland was initiated almost twenty years ago (Kolman et al. 2011, Kapusta et al. 2016, Purvina et al. 2019); This endeavor corresponds largely to the framework of the action plan developed by the Baltic Sea Environment Protection Commission (HELCOM) (Gessner et al. 2019) and the principles of the program entitled the "Pan-European Action Plan for Sturgeons" adopted by the European Commission (Friedrich et al. 2018). The success of the measures taken requires long-term cooperation among the countries and organizations involved to achieve a stable Atlantic sturgeon population in the Baltic Sea. One of the measures key to achieving the goals of these programs is optimizing breeding 
programs and especially improving feeding techniques for Atlantic sturgeon juvenile stages (Mohler 2003, Kolman et al. 2011, Gessner et al. 2019).

The success of rearing larvae depends primarily on using appropriate feed that is efficiently digested, is of the proper size, and provides nutrients to support optimal growth and survival (Hamre et al. 2013, Kandathil Radhakrishnan et al. 2020). Most larval sturgeon require live feed during initial rearing in recirculating aquaculture systems (RAS) (Chebanov et al. 2011, Gisbert et al. 2018). Research indicates that the best live feed for Atlantic sturgeon larvae is Artemia sp. nauplii (Mahler 2003, Piotrowska et al. 2013). Hatched nauplii can also be administered in either frozen and dried forms (Mohler et al. 2000, Szczepkowska et al. 2009, Cobo et al. 2014). Additionally, they can be enriched with unsaturated fatty acids (UFA), which affects larval survival significantly (Kamaszewski et al. 2014, Kolman et al. 2018). When rearing this demanding species, attention should also be paid to elements of the feeding strategy, such as feeding frequency, feed type (live or frozen), and feed size (Mohler et al. 2000, Szczepkowski et al. 2010, 2011, Kolman and Kapusta 2018).

Using frozen feed is a common practice in the breeding programs of many fish and crustacean species (Soares et al. 2006, Nascimento et al. 2020). The advantage of this type of feed is that it permits stocking and preparing quantities of it prior to planned rearing cycles, which can facilitate the process and reduce costs (Ferreira et al. 2017, Stańczak et al. 2017, Valentine et al. 2017). Currently, there is scant information in the available literature on the possibility of using frozen Artemia sp. nauplii (Mohler et al. 2000). Therefore, it is important to investigate the influence this type of feed has on larval rearing effectiveness in this species.

The size of live feed can influence larval growth (Petkam and Moodier 2001), survival (Busch et al. 2011), and pigmentation (Olsen et al. 1999) in many fish species. Feeding larvae with feed of an inappropriate size can significantly affect rearing results (Van Hoestenberghe et al. 2015). Knowledge of the diet of larval and juvenile Atlantic sturgeon in its natural habitat is very limited. According to research by
Bogacka-Kapusta (2011), juvenile Atlantic sturgeon inhabiting natural environments preferred smaller prey even though its maximum mouth opening size indicated the possibility of catching larger prey. In other sturgeon species, food choice is influenced by seasonal availability, and sturgeon can adapt to and feed on the food that is available (Miller 2004). In the literature lacks information on the preferred live feed size for sturgeon reared in RAS, although the initial rearing of Atlantic sturgeon using Artemia sp. nauplii is well described. (Mohler 2003, Kolman et al. 2018, Piotrowska et al. 2018). Using live feed of an appropriate size for the size of the mouth can significantly reduce mortality and stimulate the growth of cultured fish (Busch et al. 2011).

The aim of this study was to determine if the size and form (live or frozen) of Artemia sp. nauplius feed could limit the growth and survival of larval Atlantic sturgeon.

\section{Materials and methods}

\section{Fish}

The experiment was conducted at the Department of Sturgeon Fish Breeding (DSFB) in Pieczarki, Inland Fisheries Institute in Olsztyn. The study material was obtained from a wild population of Atlantic sturgeon inhabiting the Saint John River (Canada). Artificial spawning was performed at the hatchery of Acadian Sturgeon and Caviar, Inc. (Saint John, Canada) that is located in Carter's Point, New Brunswick, Canada. Fertilized eggs packed in polyethylene bags with water, oxygen, and activated charcoal were transported to DSFB and incubated in McDonald hatching jars placed in tanks with working volumes of $2 \mathrm{~m}^{3}$ that were part of a RAS. Mass hatching occurred after five days of incubation at $18^{\circ} \mathrm{C}$.

\section{Rearing experiment}

On the third day post hatching (DPH), 540 Atlantic sturgeon larvae were selected at random and 
transferred to nine tanks with working volumes of $0.05 \mathrm{~m} 3$ each that were part of a RAS. The system was equipped with oxygen generators and an SDK CN 3.2 biofilter (SDK, Poland) filled with synthetic RK Bioelements-Light at a total volume of $1.5 \mathrm{~m}^{3}$ (RK Plast A/S, Denmark). Larval behavior was observed daily to determine when the melanin plugs were ejected and feeding began. On the ninth DPH, the 21-day experiment began. The duration of the experiment was determined based on the optimal period during which the larvae can be fed only Artemia sp. nauplii (Mohler 2000). There were three experimental groups in which the larvae were fed live feed AF Artemia sp. with sizes of $480 \mu \mathrm{m}$ (group AD) and $\pm 430 \mu \mathrm{m}$ (group AM) and frozen AF Artemia sp. with a size of $430 \mu \mathrm{m}$ (group AI). Each of the feed variants tested was performed in three replications. The starting size of each group was 60 individuals with an average body weight of $0.006 \mathrm{~g}$ and an average total length of $1.0 \mathrm{~cm}$. The size of given nauplii was based on the manufacturer's data. The AF Artemia sp. cysts (INVE, Aquaculture, Belgium) were incubated according to the manufacturer's instructions. Frozen feed was prepared weekly from freshlyhatched $430 \mu \mathrm{m}$ nauplii, which were divided into daily feed rations and stored at $-20^{\circ} \mathrm{C}$ (Mohler et al. 2000). Before feeding, the frozen feed was thawed at room temperature. The daily feed ration was calculated with cyst dry weight at $10 \%$ of fish biomass. Live and frozen feed was administered twice daily with a $10 \mathrm{ml}$ pipette. Every morning, unconsumed feed and dead larvae, in which the degree intestinal tract fullness was determined, were removed from the tanks.

\section{Rearing conditions}

During the experiment, the mean water flow was $1.071 \mathrm{~min}^{-1}$, and the mean water temperature was $21.1^{\circ} \mathrm{C}$. The oxygen concentration at the tank outflows did not decrease below $6.4 \mathrm{mg} \mathrm{l}^{-1}$. Water $\mathrm{pH}$ was within the range of 7.9-8.1 (CyberScan 5500, Eutech Instruments, USA). The concentration of total ammonia nitrogen $\left(\mathrm{TAN}=\mathrm{NH}_{4}{ }^{+}-\mathrm{N}+\mathrm{NH}_{3}-\mathrm{N}\right)$ at the tank outflows did not exceed $0.07 \mathrm{mg} \mathrm{l}^{-1}$ and that of nitrites (NO2-N) did not exceed $0.067 \mathrm{mg} \mathrm{l}^{-1}$ (Aquamate UV-Vis Plus spectrophotometer, England). Light intensity at the surface of the tanks ranged from 87.1 to $391.1 \mathrm{~lx}$ (L-100 precision luxmeter, Sonopan, Polska).

\section{Data analysis}

All the fish from the tanks were weighed at the beginning and end of the experiment to determine their biomass. Individual measurements of body weight $( \pm 0.001 \mathrm{~g})$ and total length $( \pm 0.1 \mathrm{~cm})$ were taken of 45 specimens at the beginning of the experiment and of all fish at the end of it. Based on the data gathered, the following rearing indices were calculated: specific growth rate SGR $\left(\% \mathrm{~d}^{-1}\right)=100 \times\left(\ln \mathrm{BW}_{2}-\ln \right.$ $\left.\mathrm{BW}_{1}\right) \times \mathrm{t}^{-1}$; Fulton's condition factor $\mathrm{CF}=100 \times$ $\mathrm{BW}_{\mathrm{m}} \times \mathrm{TL}^{-3}$; body weight coefficient of variation $\mathrm{CV}$ $(\%)=100 \times \mathrm{SD} \times \mathrm{BW}^{-1}$; stock survival $\mathrm{P}(\%)=100$ $\left(\mathrm{FN} \times \mathrm{IN}^{-1}\right)$; where: $\mathrm{BW}_{1}$ and $\mathrm{BW}_{2}$ - initial and final body weight (g), BW - body weight (g), $\mathrm{BW}_{\mathrm{m}}$ - mean body weight $(\mathrm{g}) ; \mathrm{t}$ - rearing time (days); TL - total length $(\mathrm{cm})$; SD - standard deviation of body weight; IN - initial number of fish (individuals) and FN - final number of fish.

Statistical analysis was performed using Statistica 12.0 Pl (StatSoft Inc.). The homogeneity of variance was checked using Levene's test. One-way analysis of variance (ANOVA) was used to determine the significance of differences among the mean values of breeding indices in the analyzed groups. If statistically significant differences were found, further analysis was performed using Tukey's test at a significance level $\mathrm{P} \leq 0.05$. The results were expressed as the mean values of the groups $\pm \mathrm{SD}$.

\section{Results}

Feeding Atlantic sturgeon larvae feeds of different sizes and forms significantly influenced their growth. The fish from group AD had a significantly higher mean body weight and mean total length in 
Table 1

Selected rearing indices of Atlantic sturgeon (A. oxyrinchus) larvae fed Artemia sp. nauplii of the following sizes: $480 \mu \mathrm{m}$ (group $\mathrm{AD}$ ), $430 \mu \mathrm{m}$ (group $\mathrm{AM}$ ), and $430 \mu \mathrm{m}$ frozen (group AI) (mean values $\pm \mathrm{SD} ; \mathrm{n}=3$ )

\begin{tabular}{llll}
\hline & \multicolumn{2}{l}{ Group } & \\
\cline { 2 - 4 } Parameters & $\mathrm{AD}$ & $\mathrm{AM}$ & $\mathrm{AI}$ \\
\hline \hline Initial body weight (BW, g) & $0.006 \pm 0.001^{\mathrm{a}}$ & $0.006 \pm 0.001^{\mathrm{a}}$ & $0.006 \pm 0.001^{\mathrm{a}}$ \\
Final body weight (BW, g) & $0.131 \pm 0.018^{\mathrm{a}}$ & $0.071 \pm 0.005^{\mathrm{b}}$ & $0.033 \pm 0.015^{\mathrm{c}}$ \\
Initial total length (TL, cm) & $1.0 \pm 0.1^{\mathrm{a}}$ & $1.0 \pm 0.1^{\mathrm{a}}$ & $1.0 \pm 0.1^{\mathrm{a}}$ \\
Final total length (TL, cm) & $2.8 \pm 0.1^{\mathrm{a}}$ & $2.4 \pm 0.1^{\mathrm{b}}$ & $1.8 \pm 0.2^{\mathrm{c}}$ \\
Body weight coefficient of variation (CV, \%) & $55.4 \pm 5.2^{\mathrm{a}}$ & $44.3 \pm 11.9^{\mathrm{a}}$ & $49.3 \pm 18.5^{\mathrm{a}}$ \\
Specific growth rate (SGR, \% d $\left.\mathrm{d}^{-1}\right)$ & $14.7 \pm 0.6^{\mathrm{a}}$ & $11.8 \pm 0.3^{\mathrm{a}}$ & $7.8 \pm 2.0^{\mathrm{b}}$ \\
Fulton's condition factor (CF) & $0.58 \pm 0.04^{\mathrm{a}}$ & $0.54 \pm 0.04^{\mathrm{a}}$ & $0.51 \pm 0.02^{\mathrm{a}}$ \\
\hline \hline
\end{tabular}

Groups with the same letter index in the same row do not differ significantly statistically $(\mathrm{P}>0.05)$

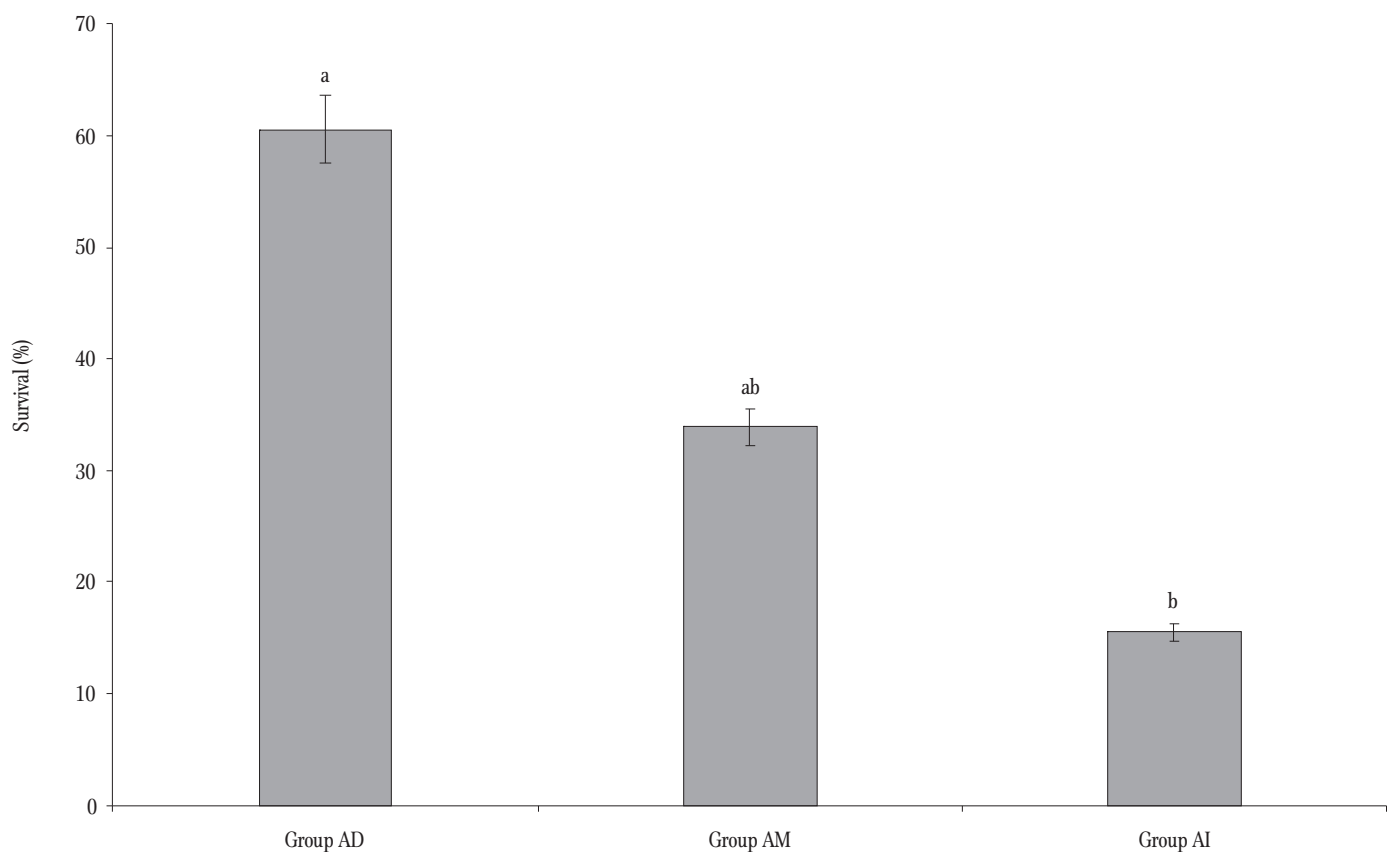

Figure 1. Effect of the size and form of Artemia sp. nauplii feed on the survival of Atlantic sturgeon (A. oxyrinchus) larvae during a 30 day rearing period. Experimental groups: AD - $480 \mu \mathrm{m}$ Artemia sp. nauplii, AM - $430 \mu \mathrm{m}$ Artemia sp. nauplii, AI - $430 \mu \mathrm{m}$ frozen Artemia sp. nauplii. Data are mean values $\pm \mathrm{SD} ; \mathrm{n}=3$. Groups means with different letters are significant different $(\mathrm{P}<0.05)$.

comparison to the other groups $(\mathrm{P} \leq 0.05$; Table 1$)$. The specific growth rates (SGR) of fish fed live Artemia sp. nauplii differed significantly from the group fed frozen feed (P $\leq 0.05$; Table 1$)$. Survival in the groups fed either live or frozen feed was $15.6 \%$ (group AI), 33.9\% (group AM), and 60.6\% (group $\mathrm{AD})$. Significant differences were confirmed in survival between groups $\mathrm{AD}$ and $\mathrm{AI}(\mathrm{P} \leq 0.05$; Fig. 1$)$. The different feed sizes and forms of live feed did not influence the condition factor or the coefficient of variation of fish body weight.

Increased mortality was observed in all the groups analyzed immediately after feeding began (Fig. 2). The highest mortality was recorded between 12 and $18 \mathrm{DPH}$. It was highest in the group fed frozen Artemia sp. nauplii at a maximum of $13.3 \%$ of the fish stock daily. On the final day of the experiment, group AI had the highest number of specimens 


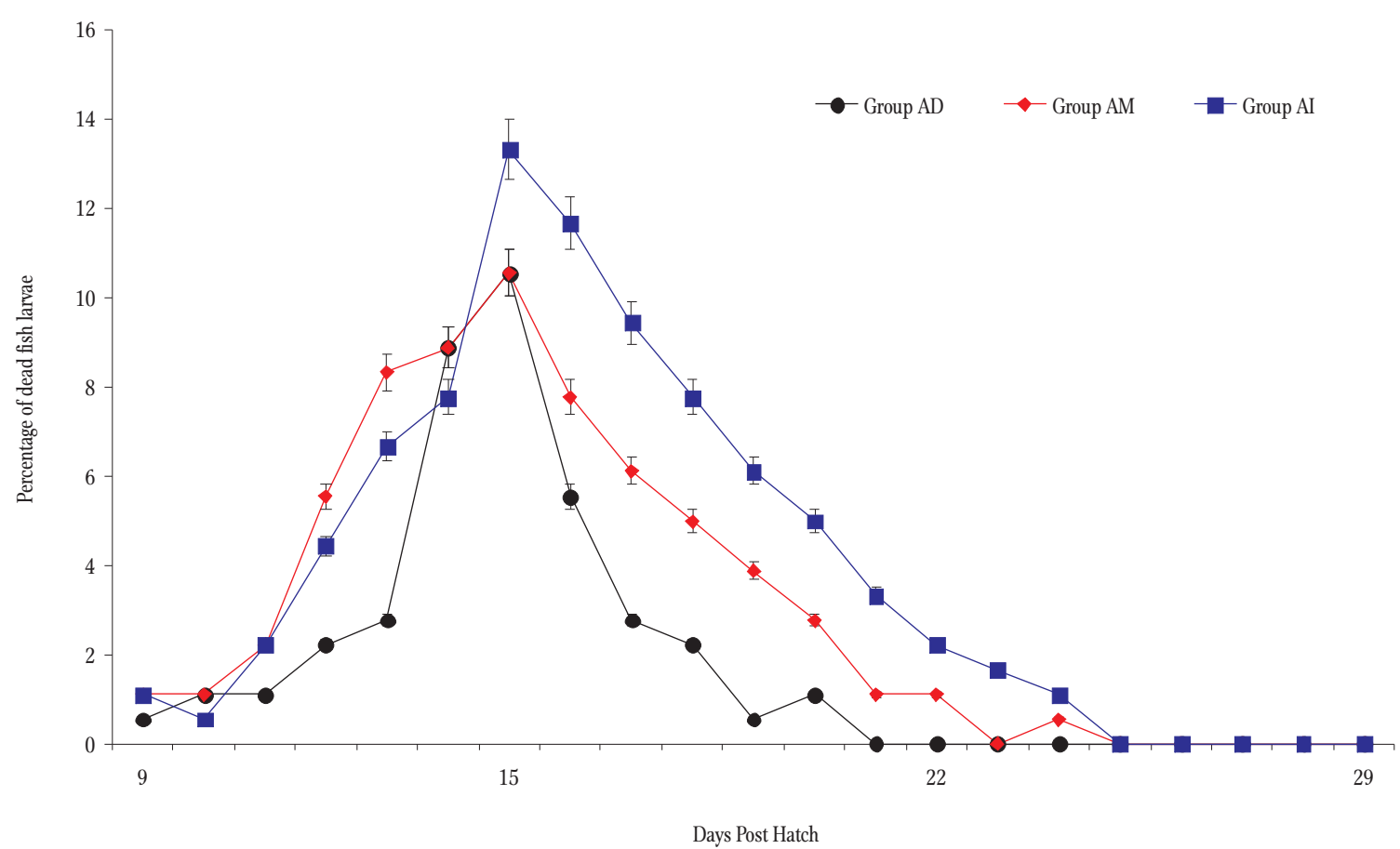

Figure 2. Effect of the size and form of Artemia sp. nauplii feed on the daily mortality of Atlantic sturgeon (A. oxyrinchus) larvae during a 30 day rearing period. Experimental groups: AD - $480 \mu \mathrm{m}$ Artemia sp. nauplii, AM - $430 \mu \mathrm{m}$ Artemia sp. nauplii, AI - $430 \mu \mathrm{m}$ frozen Artemia sp. nauplii. Data are mean values $\pm \mathrm{SD} ; \mathrm{n}=3$.

that had starved to death among all deaths. Their share of the total number of dead larvae was $93.5 \%$, while in the other groups it was $90.2 \%$ (group AD) and $74.2 \%$ (group AM). Conversely, the proportion of fully fed individuals in the groups was $6.5 \%$ in AI, $9.8 \%$ in $\mathrm{AD}$, and $25.8 \%$ in $\mathrm{AM}$.

\section{Discussion}

Sturgeons are among the most endangered fish species (IUCN 2020). The decline in natural populations is the result of the influence of long-term human activity on aquatic ecosystems, primarily industrial development, agriculture, land drainage, river regulation and development, and intense fisheries (Kolman et al. 2011). Therefore, stocking remains one of the basic tools in maintaining sustainable populations, especially those included in restoration programs. Rearing stocking material in hatcheries is one of the key elements of the restoration plan for the Baltic Sea Atlantic sturgeon population. Providing the appropriate feed for reared fish guarantees not only high fish growth rates, but also higher fish survival rates (Kolman and Kapusta 2018). Many factors influence which prey larval fish choose including characteristics of the fish species (mouth size, larval size) and the prey species (size, mobility, nutritional value) (Busch et al. 2011, Ma et al. 2015, Estévez et al. 2019, Nascimento et al. 2020).

\section{Prey size}

The Atlantic sturgeon, like most species of the genus Acipenser, is a typical benthophage. In its natural range of occurrence its prey includes benthic organisms, inter alia, crustaceans (Gammaridae, Assellidae, Anthuridae) and insect larvae (Chironomidae, Trichopterai, Ephemeroptera, Ceratopogonidae, Simuliidae) (Bogacka-Kapusta et al. 2011, Hilton et al. 2016). The composition of the natural diet of sturgeon changes depending on the developmental stage, season of the year, and feeding ground location (Guilbart et al. 2007, McLean et al. 2013). Under controlled conditions for larval sturgeon rearing, the most frequently used feed is 
Artemia sp. nauplii that are either freshly hatched (instar I) or enriched (instar II) (Kamaszewski et al. 2014, Kolman et al. 2018, Piotrowska et al. 2018). Artemia sp. cysts from America, Asia, Australia, and Europe are currently available on the market (Lavens and Sorgeloos 2000), which differ in nutritional content and size (Sorgeloos et al. 2001). Depending on the Artemia species, the nauplii range in size from $400-600 \mu \mathrm{m}$, while a specially selected type ranging in size from 660 to $790 \mu \mathrm{m}$ is recommended for larger larval fish (Camarago et al. 2005). For larval marine fishes, which have very small mouth openings and ingest prey whole, nauplius size is especially important. Correlations between nauplius size and larval fish mortality indicates that $20 \%$ of larvae starve if nauplii larger than $480 \mu \mathrm{m}$ are used in the first stages of rearing, which is why it is essential to choose the appropriate nauplius size depending on the developmental stage of the cultured larval fish (Léger et al. 2000). In the current experiment, nauplii (instar I) of $430 \mu \mathrm{m}$ and $480 \mu \mathrm{m}$ were used, and the fish fed $480 \mu \mathrm{m}$ nauplii achieved substantially better growth and survival rates. Using feed that is too small resulted in lower growth and survival rates probably because this feed did not meet fish energy requirements. Petkam and Moodie (2001) reported similar results rearing larval bighead catfish, Clarias macrocephalus (Günther). In the natural environment, as larval fish grow they choose larger prey (Busch et al. 2009) that provide more energy (Gill 2003). According to Busch et al. (2011), providing feed of a small size can stimulate growth and survival only to a certain stage of rearing, and in the case of larval cod, Gadus morhua, (L.) this was until 20 DPH. In the present study, it was revealed that nauplius size $(430 \mu \mathrm{m})$ became a limiting factor for survival and growth from $15 \mathrm{DPH}$. Larvae from group AM consumed a larger quantity of nauplii to compensate for the small size of this feed. The consequence of this was that inactive larvae ate excessively and mortality increased. The share of overfed dead specimens in this group was $25.8 \%$, while in the other groups it was lower at 9.8\% (AD) and 6.5\% (AI). Gisbert and Williot (1997) reported that the share of dead Siberian sturgeon, Acipenser baerii (Brandt), larvae with feed in their stomachs was $70-75 \%$. The deaths of overfed larvae is typical in Atlantic sturgeon, which can stem from the larvae being unable to digest the large quantities of Artemia sp. nauplii in their digestive tracts (Szczepkowski et al. 2010, Piotrowska et al. 2018). Ma et al. (2015) reported that continuous feeding at high prey density can be detrimental to fish since it overstimulates the fish to feed increasing the time it takes to void the intestines and reducing digestive efficiency.

High losses during the initial period of rearing sturgeon species is usually attributed to nutritional problems. According to Chebanov and Galich (2013), one of the primary causes of high larval mortality at the beginning of feeding is the underdeveloped digestive system. During this stage, Kolman et al. (2018) observed a sudden increase in the activity of hydrolytic enzymes in Atlantic sturgeon larvae. Mortality stabilizes later and is associated with fully developed and functioning digestive systems (Ostaszewska et al. 2011). Mortality dynamics in the present experiment was characteristic for larvae of this species (Szczepkowski et al. 2010, Kolman et al. 2018, Piotrowska et al. 2018). Until 15 DPH, the larvae that died had not yet begun feeding, while in a later stage of rearing, those that died either starved or overate. In the group fed large nauplii, mortality were lower, which could be explained by, among other factors, the more advantageous energy profile of the larger feed.

The small size of larval Atlantic sturgeon in comparison with other sturgeon species influenced the choice of the size range of the first feed. Its mean body weight of 0.006-0.008 $\mathrm{g}$ is smaller than that of larval sterlet, Acipenser ruthenus (L.), which is 0.010-0.012 g (Kolman et al. 2018). According to Kolman and Kapusta (2018), sturgeon size has a significant influence on dietary composition. The results of long-term studies indicated a correlation between the optimum size of feed and mouth opening size (Cunha and Planas 1999, Yúfera and Darias 2007, Azfar Ismail et al. 2019). Mouth size in sturgeons is relatively large in relation to body size, but, despite this, in comparison to other fish of a similar body size they prefer feed of a smaller size (Miller 2004). The 
mechanism of ingesting feed in sturgeons depends on the species. The mouths of predatory sturgeons open to the front, while those of benthic feeding sturgeons are directed downward (Zarri and Palkovacs 2019). However, this type of feeding limits maximum prey size and is not effective for catching large or highly mobile prey (Miller 2004). Thus, sturgeons ingest food selectively depending on prey size and prefer small, benthic invertebrates of low mobility (Carroll and Wainwright 2003). Even large adults of most sturgeon species prefer very small prey (Miler 2004, Hilton et al. 2016). Atlantic sturgeon mouth size relative to body size is the smallest among sturgeon species (Sulak et al. 2016), while the white sturgeon, Acipenser transmontanus Richardson, 1836, has a substantially larger mouth that permits it to ingest larger prey (Vecsei and Peterson 2004). In many species of larval marine and freshwater fish the range of the ratio of mouth size to prey size is $25-60 \%$ (Rønnestad et al. 2013, Nass et al. 2016). According to Azfar Ismai et al. (2019), larval feed must not be too small or too large. As long as prey size does not interfere with the larval swallowing mechanism (Caroll and Wainwright 2003), feeding larger nauplii (of higher individual energy content) to larvae is beneficial since they expend less energy ingesting a smaller quantity of larger nauplii. In the present experiment the larvae had no difficulty ingesting both nauplius sizes; however, using the smaller nauplii limited larval weight gain and body length growth.

\section{Live and frozen feed}

Frozen feed is usually used for the several to a dozen or more days during the beginning stage of rearing when larvae cannot yet digest formulated feed or prior to release as stocking material (Williot et al. 2005). The frozen feeds used most frequently in sturgeon rearing are Artemia sp. nauplii, Chironomidae sp. larvae, and Copepoda sp. microcrustaceans (Mohler et al. 2000, Kynard et al. 2014, Aloisi et al. 2019). Using live and frozen Artemia sp. nauplii in the rearing of lake sturgeon, Acipenser fulvescens (Rafinesque), and Atlantic sturgeon did not lower survival, but it did limit body weight and total length (Mohler et al. 2000, Valentine et al. 2017). Larval Atlantic sturgeon fed frozen feed were 35\% smaller than those fed live feed (Mohler et al. 2000). In the present experiment, the larvae fed frozen Artemia sp. nauplii were also $25 \%$ smaller, but larval survival was significantly lower in comparison to the groups fed live feed. Although the Atlantic sturgeon larvae ingested the frozen nauplii, they probably did not meet their nutritional requirements. Sharma and Chakrabarti (2009) reported that the confirmed decrease in fat and protein contents of 4 and $7 \%$, respectively, in thawed zooplankton significantly reduced growth and survival rates of larval Catla catla (Hamilton). Grabner et al. (1981) demonstrated that within 10 minutes most zooplankton nutrients are flushed out if they are thawed improperly. Hamre et al. (2013) also indicated that thawed Artemia sp. nauplii can inhibit the growth of reared fish, which was also observed in the current study.

Feeding larvae with live feed stimulates then to feed (Conceiçăo et al. 2010, Kandathil Radhakrishnan et al. 2020). It has been demonstrated that the olfactory organs develop in the embryonic phase. However, the ability to receive taste stimuli does not develop until the initiation of exogenous feeding (Kasumyan 2018). This is how the behaviors influencing the search for and capture of food begin to take shape in the larval stage; thus, using feed with an inappropriate taste or smell can negatively affect larvae and lead to variation in size or increased mortality (Kolman and Kapusta 2018). The reaction of fish to feed can be triggered by some amino acids (Kasumyan and Taufik 1994, Kasumyan 2018), the quantities of which can be reduced in frozen feeds (Grabner et al. 1981), and fish can also be less responsive to such feeds. In the natural environment, larval Atlantic sturgeon are benthophagous (Kynard and Horgan 2002) so frozen Artemia sp. nauplii can be more readily available to feeding larvae than are mobile nauplii. Additionally, the energy expended on catching feed is low in comparison to that of actively swimming prey. The results of the present study indicated that frozen feed can limit larval growth rates, which were significantly 
lower in larvae fed frozen feed $\left(7.8 \% \mathrm{~d}^{-1}\right)$ than in those fed live feed. According to Mohler et al. (2000), an SGR coefficient of $6.45-7.32 \% \mathrm{~d}^{-1}$ did not guarantee adequate larval Atlantic sturgeon growth that would permit them to attain the minimal size required to begin feeding on formulated feed. However, the growth rates of larvae fed live feed in the current study were from 11.8 to $14.7 \%$. The effects of rearing were comparable to our previous studies of Atlantic sturgeon (Kolman et al. 2008, Szczepkowski et al. 2010, Piotrowska et al. 2018).

The results of the current study indicated that the size and form of the administered live food significantly affect the rearing parameters of Atlantic sturgeon larvae. The best results gave use of live Artemia sp. nauplii with a size of $480 \mu \mathrm{m}$. Frozen Artemia sp. nauplii can be used as backup feed if live feed is unavailable. The findings of the current study provide basic information on the topic of feeding strategies. Further research is required on the possibility of using frozen feed and also on the maximum size of Artemia sp. nauplii that could be used in the rearing of Atlantic sturgeon larvae. This will permit optimizing rearing technologies for this species in RAS.

Acknowledgments. This research was supported by the S. Sakowicz Inland Fisheries Institute under research project numbers S-027.

Author contributions. I.P. designed the research; I.P., B.SZ., M.K. performed the experiment; I.P., M.K. analyzed the data; I.P. wrote the paper. All authors read and approved the final manuscript.

\section{ORCID iD}

Iwona Piotrowska（iD 0000-0002-0495-3568

Bożena Szczepkowska iD 0000-0002-0164-4647

Michał Kozłowski (iD 0000-0001-7769-7051

\section{References}

Aloisi, D. B., Eckes, O. T., Von Eschen, A. J. (2019). Development of a growth model for lake sturgeon. North American Journal of Aquaculture, 81(4), 399-405.

Azfar-Ismail, M., Kamarudin, M. S., Syukri, F., Latif, K. (2020). Larval development of a new hybrid Malaysian mahseer (Barbonymus gonionotus $+9 \times$ Tor tambroides $\left.\sigma^{\top}\right)$. Aquaculture Reports, 18, 100416.

Bogacka-Kapusta, E., Wiszniewski, G., Duda, A., Kapusta, A. (2011). Feeding of hatchery-reared juvenile Atlantic sturgeon, Acipenser oxyrinchus Mitchill, released into the Drwęca River. Archives of Polish Fisheries, 19, 113-117.

Busch, K. E. T., Falk-Petersen, I. B., Peruzzi, S., Rist, N. A., Hamre, K. (2010). Natural zooplankton as larval feed in intensive rearing systems for juvenile production of Atlantic cod (Gadus morhua L.). Aquaculture Research, 41(12), 1727-1740.

Busch, K. E. T., Peruzzi, S., Tonning, F., Falk-Petersen, I. B. (2011). Effect of prey type and size on the growth, survival and pigmentation of cod (Gadus morhua L.) larvae. Aquaculture Nutrition, 17(2), e595-e603.

Camargo, W. N., Durán, G. C., Rada, O. C., Hernández, L. C., Linero, J. C. G., Muelle, I. M., Sorgeloos, P. (2005). Determination of biological and physicochemical parameters of Artemia franciscana strains in hypersaline environments for aquaculture in the Colombian Caribbean. Saline Systems, 1(1), 1-11.

Carroll, A. M., Wainwright, P. C. (2003). Functional morphology of prey capture in the sturgeon, Scaphirhynchus albus. Journal of Morphology, 256(3), 270-284.

Chebanov, M. S., Galich, E. V. (2011) Sturgeon hatchery manual. FAO Fisheries and Aquaculture Technical Paper. No. 558. Ankara, FAO.

Cobo, M. D. L., Wouters, R., Wille, M., Sonnenholzner, S., Sorgeloos, P. (2015). Evaluation of frozen Umbrella stage Artemia as first animal live food for Litopenaeus vannamei (Boone) larvae. Aquaculture Research, 46(9), 2166-2173.

Conceiçăo, L. E., Yúfera, M., Makridis, P., Morais, S., Dinis, M. T. (2010). Live feeds for early stages of fish rearing. Aquaculture Research, 41(5), 613-640.

Cunha, I., Planas, M. (1999). Optimal prey size for early turbot larvae (Scophthalmus maximus L.) based on mouth and ingested prey size. Aquaculture, 175(1-2), 103-110.

Estévez, A., Papandroulakis, N., Wille, M, Sorgeloos, P. (2019). Early Life Stages and Weaning. In: Organic Aquaculture Impacts and Future Developments (Ed.) G. Lembo, E. Mente, Springer Nature Switzerland AG: 79-102.

Friedrich, T., Gessner, J., Reinartz, R., Striebel-Greiter, B. (2018). Draft Pan-European action plan for sturgeons. Council of Europe.

https://rm.coe.int/pan-european-action-plan-for-sturge ons/16808e84f3

Gessner, J., Arndt, G-M., Kapusta, A., Shibayev, S., Gushin, A., Pilinkovskij, A., Povliūnas, J., Medne, R., Purvina, S., Tambets, M., Möller, P. R. (2019). HELCOM Action Plan for the protection and recovery of Baltic sturgeon Acipenser oxyrinchus oxyrinchus in the Baltic Sea area. 
Baltic Sea Environment Proceedings n¹68. HELCOM, Helsinki.

Gill, A. B. (2003). The dynamics of prey choice in fish: the importance of prey size and satiation. Journal of Fish Biology, 63, 105-116.

Gisbert, E., Solovyev, M., Bonpunt, E., Mauduit, Ch. (2018). Weaning in Siberian sturgeon larvae. In: The Siberian Sturgeon (Acipenser baerii, Brandt, 1869) Volume 2 Farming. (Ed.) Williot P., Nonnotte G., Chebanov M., Springer, Cham, 59-72.

Gisbert, E., Williot, P. (1997). Larval behavior and effect of the timing of initial feeding on growth and survival of Siberian Sturgeon (Acipenser baerii) larvae under small scale hatchery production. Aquaculture, 156, 63-76.

Grabner, M., Wieser, W., Lackner, R. (1981). The suitability of frozen and freeze-dried zooplankton as food for fish larvae: a biochemical test program. Aquaculture, 26(1-2), 85-94.

Guilbart, F., Munro, J., Dumont, P., Hatin, D., Fortin, R. (2007). Feeding ecology of Atlantic sturgeon and Lake sturgeon co-occurring in the St. Lawrence Estuarine Transition Zone - American Fisheries Society Symposium, 56, 85-104.

Hamre, K., Yúfera, M., Rønnestad, I., Boglione, C., Conceiçăo, L. E., Izquierdo, M. (2013). Fish larval nutrition and feed formulation: knowledge gaps and bottlenecks for advances in larval rearing. Reviews in Aquaculture, 5, S26-S58.

Hilton, E. J., Kynard, B., Balazik, M. T., Horodysky, A. Z., Dillman, C. B. (2016). Review of the biology, fisheries, and conservation status of the Atlantic Sturgeon, (Acipenser oxyrinchus oxyrinchus Mitchill, 1815). Journal of Applied Ichthyology, 32, 30-66.

IUCN, (2021). The IUCN Red List of Threatened Species. Version 2020-3. Available at: http://www.iucnredlist.org (accessed on 15 March 2021).

Kamaszewski, M., Wójcik, M., Ostaszewska, T., Kasprzak, R., Kolman, R., Prusińska, M. (2014). Short communication The effect of essential fatty acid (EFA) enrichment of Artemia sp. nauplii on the enzymatic activity of Atlantic sturgeon (Acipenser oxyrinchus Mitchill, 1815) larvae-preliminary study. Journal of Applied Ichthyology, 30, 1256-1258.

Kapusta, A., Morzuch, J., Duda, A., Bogacka-Kapusta, E., Kolman, R. (2016). Dispersal and survival of stocked juvenile hatchery-reared Atlantic sturgeon (Acipenser oxyrinchus). Archives of Polish Fisheries, 24, 243-249.

Kandathil Radhakrishnan, D., AkbarAli, I., Schmidt, B. V., John, E. M., Sivanpillai, S., Thazhakot Vasunambesan, S. (2020). Improvement of nutritional quality of live feed for aquaculture: An overview. Aquaculture Research, 51(1), $1-17$.

Kasumyan, A. (2018). Olfaction and Gustation in Acipenseridae, with Special References to the Siberian Sturgeon. In: The Siberian Sturgeon (Acipenser baerii,
Brandt, 1869) Volume 1 - Biology, (Ed.) Williot P., Nonnotte G., Vizziano-Cantonnet D., Chebanov M. Springer, Cham. 173-206.

Kasumyan, A. O., Taufik, L. R. (1994). Behavior reaction of juvenile sturgeons (Acipenseridae) to amino acids. Journal of Ichthyology, 34(2), 90-103.

Kolman, R., Kapusta, A. (2018). Food characteristics and feeding management on sturgeon with a special focus on the Siberian sturgeon. In: The Siberian Sturgeon (Acipenser baerii, Brandt, 1869) Volume 2 - Farming. (Ed.) Williot P., Nonnotte G., Chebanov M., Springer, Cham, 75-84.

Kolman, R., Kapusta, A., Szczepkowski, M., Duda, A., Bogacka-Kapusta, E. (2008). The Atlantic sturgeon, Acipenser oxyrhynchus oxyrhynchus Mitch. Wydawnictwo IRS, Olsztyn, 5-73 (in Polish).

Kolman, R., Kapusta, A., Duda, A., Wiszniewski, G. (2011). Review of the current status of the Atlantic sturgeon Acipenser oxyrinchus oxyrinchus Mitchill 1815, in Poland: principles, previous experience, and results. Journal of Applied Ichthyology, 27(2), 186-191.

Kolman, R., Khudyi, O., Kushniryk, O., Khuda, L., Prusinska, M., Wiszniewski, G. (2018). Influence of temperature and Artemia enriched with $\omega$-3 PUFA s on the early ontogenesis of Atlantic sturgeon, Acipenser oxyrinchus Mitchill, 1815. Aquaculture Research, 49(5), 1740-1751.

Kynard, B., Horgan, M. (2002). Ontogenetic behavior and migration of Atlantic sturgeon, Acipenser oxyrinchus oxyrinchus, and shortnose sturgeon, A. brevirostrum, with notes on social behavior. Environmental Biology of Fishes, 63(2), 137-150.

Kynard, B., Parker, E., Kynard, B. E., Horgan, M. (2014). Effect of velocity regime on ontogenetic dispersal and habitat use of Kootenai River White Sturgeon (Acipenser transmontanus, Richardson, 1836) early life stages: An artificial stream study. Journal of Applied Ichthyology, 30(6), 1160-1167.

Léger, P., Bengtson, D. A., Sorgeloos, P., Simpson, K. L., Beck, A. D. (1987). The nutritional value of Artemia: a review. In: Artemia research and its applications. Ecology, Culturing, Use in Aquaculture. (Ed.) Sorgeloos P., Bengtson D.A., Decleir W., Jaspers E., Universa Press, Wetteren, vol. 3, 357-372.

Lavens, P., Sorgeloos, P. (2000). The history, present status and prospects of the availability of Artemia cysts for aquaculture. Aquaculture, 181(3-4), 397-403.

Ma, Z., Guo, H., Zhang, D., Hu, C., Jiang, S. (2015). Food ingestion, consumption and selectivity of pompano, Trachinotus ovatus (Linnaeus 1758) under different rotifer densities. Aquaculture Research, 46(11), 2593-2603.

McLean, M. F., Dadswell, M. J., Stokesbury, M. J. W. (2013). Feeding ecology of Atlantic sturgeon, Acipenser 
oxyrinchus oxyrinchus Mitchill, 1815 on the infauna of intertidal mudflats of Minas Basin, Bay of Fundy. Journal of Applied Ichthyology, 29(3), 503-509.

Miller, M. J. (2004). The ecology and functional morphology of feeding of North American sturgeon and paddlefish. In: Sturgeons and paddlefish of North America. Fish \& Fisheries Series, vol 27. (Ed.) LeBreton G.T.O., Beamish F.W.H., McKinley R.S., Springer, Dordrecht, 87-102.

Mohler, J. W. (2000). Early culture of the American Atlantic sturgeon Acipenser oxyrinchus oxyrinchus Mitchill, 1815 and preliminary stocking trials. Boletin. Instituto Espanol De Oceanografia, 16, 203-208.

Mohler, J. W. (2003). Culture manual for the Atlantic sturgeon Acipenser oxyrinchus oxyrinchus. U.S. Fish \& Wildlife Service, Hadley, Massachusetts, 1-66.

Mohler, J. W., King, M. K., Farrell, P. R. (2000). Growth and survival of first-feeding and fingerling Atlantic sturgeon under culture conditions. North American Journal of Aquaculture, 62(3), 174-183.

Muir, W. D., McCabe Jr, G. T., Hinton, S. A., Parsley, M. J. (2000). Diet of first-feeding larval and young-of-the-year white sturgeon in the lower Columbia River. Northwest Science, 74, 25-33.

Nascimento, M. D. P., Schorer, M., Dos Santos, J. C., Rocha, M. S., Pedreira, M. M. (2020). Live and frozen Artemia nauplii for catfish Lophiosilurus alexandri (Steindachner, 1876) larvae in different salinities. Tropical Animal Health and Production, 52(2), 653-659.

Nass, D. H., Gonçalves, E. L. T., Tsuzuki, M. Y. (2016). Effect of live food transition time on survival, growth and metamorphosis of yellowtail clownfish, Amphiprion clarkii, larvae. Aquaculture International, 24(5), 1255-1261.

Olsen, A. I., Attramadal, Y., Jensen, A., Olsen, Y. (1999). Influence of size and nutritional value of Artemia franciscana on growth and quality of halibut larvae (Hippoglossus hippoglossus) during the live feed period. Aquaculture, 179(1-4), 475-487.

Ostaszewska, T., Kamaszewski, M., Kolman, R., Wiszniewski, G., Adamek, D., Duda, A. (2011). Morphological changes in digestive tract of Atlantic sturgeon Acipenser oxyrinchus during organogenesis. International Aquatic Research, 3(2), 101-105.

Ostos-Garrido, M. V., Llorente, J. I., Camacho, S., García-Gallego, M., Sanz, A., Domezain, A., Carmona, R. (2009). Histological, histochemical and ultrastructural changes in the digestive tract of sturgeon Acipenser naccarii during early ontogeny. In: Biology, conservation and sustainable development of sturgeons (Ed.) Carmona R., Domezain A., García-Gallego M., Hernando J.A., Rodríguez F., Ruiz-Rejón M., Springer, Dordrecht, 121-136.

Petkam, R., Moodie, G. E. E. (2001). Food particle size, feeding frequency, and the use of prepared food to culture larval walking catfish (Clarias macrocephalus). Aquaculture, 194(3-4), 349-362.

Purvina, S., Pliksh, M., Medne, R. (2019). Review of the history to the present of Atlantic sturgeon (Acipenser oxyrinchus) in Latvian marine and inland waters with evidence from archeological sites. Fisheries \& Aquatic Life, 27, 3-14.

Piotrowska, I., Szczepkowska, B., Szczepkowski, M., Kozłowski, M. (2018). Assessment of the impact of the timing of first feeding with live and formulated feeds on the survival and growth of larvae Atlantic sturgeon (Acipenser oxyrinchus Mitchill) in recirculating systems. Fisheries \& Aquatic Life, 26(2), 111-120.

Piotrowska, I., Szczepkowska, B., Kozłowski, M., Wunderlich, K., Szczepkowski, M. (2013). Results of the larviculture of Atlantic sturgeon (Acipenser oxyrinchus) fed different types of diets. Archives of Polish Fisheries, 21(1), 53-61.

Rønnestad, I., Yúfera, M., Ueberschär, B., Ribeiro, L., Sćle, Ø., Boglione, C. (2013). Feeding behaviour and digestive physiology in larval fish: current knowledge, and gaps and bottlenecks in research. Reviews in Aquaculture, 5, S59-S98.

Russo, T., Boglione, C., De Marzi, P., Cataudella, S. (2009). Feeding preferences of the dusky grouper (Epinephelus marginatus, Lowe 1834) larvae reared in semi-intensive conditions: a contribution addressing the domestication of this species. Aquaculture, 289(3-4), 289-296.

Sharma, J. G., Chakrabarti, R. (2009). Comparative growth performance and proteolytic enzyme activity of Indian major carp larvae, fed with live food and refrigerated-plankton food. Indian Journal of Animal Sciences, 79(11), 1185-1188.

Soares, R., Peixoto, S., Wasielesky, W., D'Incao, F. (2006). Effect of different food items on the survival and growth of Farfantepenaeus paulensis (Pérez-Farfante 1967) postlarvae. Aquaculture Research, 37(14), 1413-1418.

Sorgeloos, P., Dhert, P., Candreva, P. (2001). Use of the brine shrimp, Artemia spp., in marine fish larviculture. Aquaculture, 200(1-2), 147-159.

Stakènas, S., Pilinkovskij, A. (2019). Migration patterns and survival of stocked Atlantic sturgeon (Acipenser oxyrinchus Mitchill, 1815) in Nemunas Basin, Baltic Sea. Journal of Applied Ichthyology, 35(1), 128-137.

Stańczak, K., Mierzejewska, K., Król, J., Hliwa, P. (2017). The use of live and frozen Artemia salina nauplii enriched with fluorochromes for mass - marking vendace Coregonus albula (L.) larvae. Journal of Applied Ichthyology, 33(6), 1173-1177.

Szczepkowska, B., Szczepkowski, M., Kolman, R. (2009). Impact of feeding on the culture of larval hybrid Siberian sturgeon (Acipenser baerii) with Russian sturgeon (Acipenser gueldenstaedtii). In: Reproduction, culture, and prophylactics in salmonids and other fish species (Ed.) Zakęś Z., Demska-Zakęś K., Kowalska A., 
Ulikowski D., Wydawnictwo IRS, Olsztyn, 301-306 (in Polish).

Szczepkowski, M., Szczepkowska, B., Piotrowska, I. (2011). Impact of higher stocking density of juvenile Atlantic sturgeon, Acipenser oxyrinchus Mitchill, on fish growth, oxygen consumption, and ammonia excretion. Archives of Polish Fisheries, 19(2), 59-67.

Szczepkowski, M., Szczepkowska, B., Kolman, R., Piotrowska, I. (2010). Using Artemia salina in a larviculture system for Atlantic sturgeon (Acipenser oxyrinchus) - Results and observations of larval sturgeon cultured on a semi-production scale. In: Reproduction, culture, and prophylactics for rare fish and those under conservation and other species (Ed.) Zakęś Z., Demska-Zakęś K., Kowalska A., Wydawnictwo IRS, Olsztyn, 143-149 (in Polish).

Sulak, K. J., Parauka, F., Slack, W. T., Ruth, R. T., Randall, M. T., Luke, K., Mettee, M. F., Price, M. E. (2016). Status of scientific knowledge, recovery progress, and future research directions for the Gulf Sturgeon, Acipenser oxyrinchus desotoi Vladykov, 1955. Journal of Applied Ichthyology, 32, 87-161.

Valentine, S. A., Bauman, J. M., Scribner, K. T. (2017). Effects of alternative food types on body size and survival of hatchery-reared Lake Sturgeon larvae. North American Journal of Aquaculture, 79(4), 275-282.

Van Hoestenberghe, S., Wille, M., De Swaef, E., Goddeeris, B. M., Nevejan, N. (2015). Effect of weaning age and the use of different sized Artemia nauplii as first feed for jade perch Scortum barcoo. Aquaculture International, 23(6), 1539-1552.

Vecsei, P., Petrrson, D. (2004). Sturgeon ecomorphology: a descriptive. In: Sturgeons and paddlefish of North America. Fish \& Fisheries Series, vol 27. (Ed.) LeBreton G.T.O., Beamish F.W.H., McKinley R.S., Springer, Dordrecht, 103-133.

War, M., Altaff, K., Haniffa, M.A. (2011). Growth and survival of larval Snakehead Channa striatus (Bloch, 1793) fed different live feed organisms. Turkish Journal of Fisheries and Aquatic Sciences, 11, 523-528.

Williot, P., Brun, R., Rouault, T., Pelard, M., Mercier, D. (2005). Attempts at larval rearing of the endangered western European sturgeon, Acipenser sturio (Acipenseridae), in France. Cybium, 29(4), 381-387.

Yúfera, M., \& Darias, M. J. (2007). The onset of exogenous feeding in marine fish larvae. Aquaculture, 268(1-4), 53-63.

Zarri, L. J., Palkovacs, E. P. (2019). Temperature, discharge and development shape the larval diets of threatened green sturgeon in a highly managed section of the Sacramento River. Ecology of Freshwater Fish, 28(2), 257-265. 